\title{
Sugarcane Field Residue and Bagasse Allelopathic Impact on Vegetable Seed Germination
}

\author{
Charles L. Webber III ${ }^{1}$, Paul M. White Jr. ${ }^{1}$, Derek S. Landrum ${ }^{1}$, Douglas J. Spaunhorst ${ }^{1} \&$ Darcey G. Wayment ${ }^{2}$ \\ ${ }^{1}$ USDA, Agriculture Research Service, Sugarcane Research Unit, Houma, LA, USA \\ ${ }^{2}$ Department of Physical Sciences, Nicholls State University, Thibodaux, LA, USA \\ Correspondence: Charles L. Webber III, USDA, Agriculture Research Service, Sugarcane Research Unit, Houma, \\ LA 70360, USA. E-mail: chuck.webber@ars.usda.gov
}

\author{
Received: August 4, $2017 \quad$ Accepted: September 3, $2017 \quad$ Online Published: October 15, 2017 \\ doi:10.5539/jas.v9n11p10 URL: https://doi.org/10.5539/jas.v9n11p10
}

\begin{abstract}
The chemical interaction between plants, which is referred to as allelopathy, may result in the inhibition of plant growth and development. The objective of this research was to determine the allelopathic impact of sugarcane (Saccharum officinarum) var. 'HoCP 96-540' field residue and sugarcane bagasse extracts on the germination of three vegetable crops. Tomato (Solanum lycopersicum L.), Chinese kale (Brassica oleracea L. var. alboglabra Bailey), and cucumber (Cucumis sativus L.) seeds were treated with 4 extract concentrations $(0,16.7,33.3$, and $66.7 \mathrm{~g} / \mathrm{L}$ ) from either sugarcane field residue or sugarcane bagasse extracts. Germination of the tomato, Chinese kale, and cucumber seeds decreased as concentration of sugarcane field residue extracts increased. At the highest residue concentration $(66.7 \mathrm{~g} / \mathrm{L})$, germination decreased by $44 \%, 82 \%$, and $88 \%$ for tomato, Chinese kale, and cucumber, respectively. These results would indicate that sugarcane field residue would not be a suitable natural mulch or soil amendment for local vegetable production, especially where the vegetables were direct-seeded. If evaluated correctly, the sugarcane field residue may be an effective natural mulch for perennial ornamental plants in landscape applications, serving as a physical and chemical barrier to germinating and emerging weed species. Sugarcane bagasse extracts did not inhibit Chinese kale and cucumber germination, and only inhibited tomato germination by $13 \%$ at the greatest concentration $(66.7 \mathrm{~g} / \mathrm{L})$ in 1 experiment. As the first documented bioassay implicating bagasse as allelopathic active, further research should investigate the subject using higher concentrations, and additional sugarcane and tomato varieties. Except for the one instance with tomato germination, it appears that sugarcane bagasse has potential as a natural mulch for vegetable production, although the mulch would only be a physical barrier to weed establishment and not a allelopathic chemical barrier. Future research should determine the allelopathic active compounds in sugarcane field residue and if the concentration of allelopathic chemicals vary by sugarcane variety.
\end{abstract}

Keywords: allelopathy, bagasse, Chinese kale, cucumber, pestiphytology, seed germination, sugarcane, tomato

\section{Introduction}

\subsection{Allelopathy}

Allelopathy, coined and defined by Molisch (1937), is the biochemical interaction between plants including either inhibition or stimulation of the plant growth and development. Many plant species produce compounds that when released into the environment can impact the growth and development of other plants (Rice, 1984). These compounds may be produced in a plant's leaves, stems, or roots, and either exuded from the plant parts, leached from the plant material, or transformed by microbial activity to become allelopathic (Rice, 1984). The demand by the general public for more naturally produced crops is a positive incentive to explore the use of natural plant chemicals to either promote crop growth and production, or inhibit weed growth and development (Bowmick \& Doll, 1982; Rice, 1984; Russo et al., 1997a, 1997b; Webber et al., 2015a, 2015b). The identification and modes of action of allelopathic compounds are used to produce natural herbicides and in the development of synthesized herbicides which are closely related the allelopathic compounds (Duke \& Dayan, 2013; Gerwick \& Sparks, 2014; Nimbal et al., 1996). 


\subsection{Sugarcane and Allelopathy}

Several studies have characterized allelopathic compounds in sugarcane leaves (De Carvalho et al., 1996; Singh et al., 2003; Viator et al., 2006). For example, Viator et al. (2006) reported benzoic acid from post-harvest sugarcane field residue, variety 'LCP 85-384'. Benzoic acid and its derivatives have been shown to be allelopathic to cotton (Gossypium hirsutum L.) (Lodhi et al., 1987), wheat (Triticum aestivum L.) (Lodhi et al., 1987) and ryegrass (Lolium spp.) (Wu et al., 2002). The commercial herbicide dicamba (3,6-dichloro-2-methoxy benzoic acid) is a benzoic acid compound. Sugarcane field residue leachates in two soil types reduced germination and radical growth of oat (Avena nuda L.) and rye (Secale cereale L.), but not tomato (Solanum lycopersicum L.) (Viator et al., 2006).

Sugarcane field residue leachates also reduced the growth of numerous weedy species, such as arrowleaf sida (Sida rhombifolia L.) (Sampietro et al., 2007). Three allelopathic compounds, ferulic, vanillic and syringic acids that exhibited allelopathic characteristics have been isolated from sugarcane field residue leachates (Sampietro et al., 2005; Sampietro \& Vattuone, 2006b). Beggarticks (Bidens subalternans L.) and wild mustard (Brassica campestris L.) seedling root elongation was reduced due to the presence of phenolic compounds (Sampieto \& Vattuone, 2006a). Phenolic commercial herbicides are commonly used in production agriculture (i.e. bromoxynil and isonil) (Takahashi et al., 2010).

Depending on the concentration, sugarcane leachate has either promoted or inhibited growth (Sampietro \& Vattuone, 2006b). At sugarcane field residue levels typically found in the field, the leachate would inhibit growth, but at a lower $6 \mathrm{~g} / \mathrm{L}$ concentration the extract promoted root growth of pigweed (Amaranthus quitensis L.), radish (Raphanus sativus L. var. 'Sparkler'), sorghum (Sorghum bicolor [L.] Moench var. 'Supergauchazo'), wheat (Triticum aestivum L. var. 'Pegaso'), and wild mustard (Brassica campestris L.) (Sampietro \& Vattuone, 2006b). Rodrigues et al. (2001) documented that the breakdown of sugarcane bagasse lignocellulosic material produced toxic compounds that inhibit cellular growth. Also, leaching or the microbial breakdown of the bagasse may have an allelopathic (toxic) impact on squash plants (Facelli \& Pickett, 1991; Rice, 1984; Rodrigues et al., 2001; Webber et al., 2017).

Organic mulches are used in vegetable production to enhance soil temperatures, retain soil moisture, prevent soil erosion, and decrease pest infestations (Webber et al., 2017). Due to the abundant annual bagasse surplus (3.5 million $\mathrm{mt} / \mathrm{yr}$ ) at Louisiana sugarcane sugar mills and the present policy of burning sugarcane field residue (70 $\mathrm{mt} / \mathrm{ha}$ ), there is a growing interest in alternative uses of these sugarcane plant materials, including as natural organic mulches for vegetable production (Webber et al., 2017). The long frost-free growing season in southern Louisiana, 230-290 days a year, that favors sugarcane production, also provides an ideal environment for vegetable production. Unfortunately, the sugarcane field residue and bagasse material also has the potential to produce allelopathic compounds that may adversely impact crop production if used as a natural mulch (Rodrigues et al., 2001; Sampietro et al., 2005, 2007; Sampietro \& Vattuone, 2006a, 2006b). Research was initiated to determine the allelopathic impact of sugarcane field residue and sugarcane bagasse extracts on seed germination of tomato, Chinese kale, and cucumber.

\section{Material and Methods}

\subsection{Plant Material Collection}

Sugarcane var. 'HoCP 96-540' (Tew et al., 2005) was harvested on Dec. 12, 2015 at the USDA, ARS, Sugarcane Research Unit, Ardoyne Farm, Schriever, LA. Immediately after harvest, sugarcane field residue (straw) was collected, this included portions of the plant material not delivered to the mill for processing: leaves, immature nodes and growing tips. 'HoCP 96-540' residue averaged $716 \mathrm{~g} / \mathrm{m}^{2}(71.6 \mathrm{mt} / \mathrm{ha})$ on an oven dry weight basis. Sugarcane mill bagasse was collected from the Raceland Raw Sugar Corporation mill in Raceland, LA in March of 2016. Sugarcane bagasse is the fibrous material remaining after removing the sucrose, water, and other impurities (filter mud) from the millable sugarcane.

\subsection{Sugarcane Extract Preparations}

The sugarcane field residue and bagasse were dried in a forced air oven at $60{ }^{\circ} \mathrm{C}$ to a constant weight. The dried material was then ground using a Thomas-Wiley Laboratory Mill with a $2 \mathrm{~mm}$ sieve. The plant material (66.7 $\mathrm{g} / \mathrm{L}$ ) and de-ionized water were added to $4000 \mathrm{ml}$ flasks and placed on a Lab-Line Orbit Shakers at $100 \mathrm{rpm}$ for $12 \mathrm{~h}$ at room temperature $\left(2{ }^{\circ} \mathrm{C}\right)$. The solutions then were vacuum filtered using a three step process; 1$)$ filtered through a Buchner funnel sans filter paper, 2) Buchner funnel with a fiber cone filter with a $8.25 \mathrm{~cm}$ diameter base (Rockline ${ }^{\circledR}, 4343$ S. Taylor Drive, Sheboygan, WI 53081 USA), and 3) Buchner funnel with a Whatman ${ }^{\circledR}$ \#2 filter (9.0 cm diameter). The samples were then diluted with de-ionized water to produce concentrations of 
$66.7 \mathrm{~g} / \mathrm{L}$ (full strength/not diluted), $33.3 \mathrm{~g} / \mathrm{L}$ (half strength), and $16.7 \mathrm{~g} / \mathrm{L}$ (quarter strength) solutions of sugarcane field residue and sugarcane bagasse extracts (Webber et al., 2005a; 2005b). A nontreated check $(0 \mathrm{~g} / \mathrm{L})$ was also included for comparison. The $\mathrm{pH}$ for all dilutions were adjusted to $7.0 \mathrm{using} 1 \mathrm{M} \mathrm{KOH}$ and $5 \% \mathrm{C}_{2} \mathrm{H}_{4} \mathrm{O}_{2}$ (acetic acid).

\subsection{Extract Treatments of the Seeds}

Tomato (Solanum lycopersicum Mill.) var. 'Celebrity F1, Hybrid' (Johnny's Selected Seeds, 955 Benton Avenue, Winstow, Maine 04901 USA), Chinese kale (Brassica oleracea L. var. alboglabra Bailey) var. 'South Sea' (Evergreen Y.H. Enterprises, P.O. Box 17538, Anaheim, CA 92817, USA), and cucumber (Cucumis sativus L.) var. 'H-19 Little Leaf OG' (Johnny's Selected Seeds, 955 Benton Avenue, Winstow, Maine 04901 USA), seeds were surface sterilized for $1 \mathrm{~min}$ using 50\% sodium hypochlorite solution. The seeds were then rinsed with de-ionized water and allowed to air dry for $10 \mathrm{~min}$. Twenty seeds of each plant species were placed in separate Petri plates which contained $9.0 \mathrm{~cm}$ Whatman ${ }^{\circledR}$ No. 2 filter paper. Each Petri plate received $10 \mathrm{ml}$ of either sugarcane field residue or sugarcane bagasse extract at one of the concentrations $(0,16.7,33.3$, and $66.7 \mathrm{~g} / \mathrm{L})$. The Petri plates were covered and placed in a non-illuminated incubator at $27^{\circ} \mathrm{C}$. Seven days later the Petri plates were removed and seed germination was measured. Seeds were considered germinated when the seed radicle was equal to or longer than the width of seed of the specific plant species being measured. The experimental design included 2 extracts sources (sugarcane field residue and sugarcane bagasse), 4 extract concentrations $(0,16.7,33.3$, and $66.7 \mathrm{~g} / \mathrm{L})$, and 3 vegetable species (tomato, Chinese kale, and cucumber). The experiment was repeated twice with 5 replications in each experiment. All data were subjected to ANOVA and mean separation using LSD with $\mathrm{P}=0.05$ (SAS Inc., SAS, Ver. 9.4, Cary, NC).

\section{Results and Discussion}

\subsection{Statistical Analysis}

Statistical analysis determined that there were significant interactions among plant species (tomato, Chinese kale, and cucumber), between Experiments (1 and 2) within plant species, and extract concentration $(0,16.7,33.3$ and $66.7 \mathrm{~g} / \mathrm{L})$, therefore the results will be discussed by plant species with each interaction addressed separately (Table 1).

Table 1. Analysis of variance (ANOVA) for percent germination of tomato, Chinese kale, and cucumber for source factors: experiments, treatments, and experiment by treatment interaction

\begin{tabular}{llll}
\hline Source & Tomato & Chinese Kale & Cucumber \\
\hline & $\operatorname{Pr}>\mathrm{F}$ & $\operatorname{Pr}>\mathrm{F}$ & $\operatorname{Pr}>\mathrm{F}$ \\
Experiment & $<0.0001$ & 0.0009 & $0.22^{\mathrm{Z}}$ \\
Treatment & $<0.0001$ & $<0.0001$ & $<0.0001$ \\
Experiment $\times$ Treatment & $<0.0001$ & 0.0074 & $<0.0001$ \\
\hline
\end{tabular}

Note. ${ }^{\mathrm{Z}}$ Not significantly different.

\subsection{Tomato}

The sugarcane bagasse inhibited tomato germination 13\%, but only in Experiment 2 at the greatest concentration $(66.7 \mathrm{~g} / \mathrm{L})$ (Table 2). This is the first bioassay documenting that sugarcane bagasse has an allelopathic impact. Rodrigues et al. (2001) did confirm the presence furfural, hydroxymethylfurfural, and phenol compounds, which are all toxic compounds that inhibit cellular growth, when sugarcane bagasse was hydrolyzed, but did not conduct a bioassay. Although these toxic compounds are present in sugarcane bagasse, it appears that their concentration is not great enough or they are not typically released through the water extraction method employed by the authors.

In Experiments 1 and 2, the sugarcane field residue decreased tomato seed germination at $66.7 \mathrm{~g} / \mathrm{L}$ by $17 \%(97 \%$ $-80 \%=17 \%)$ and $71 \%(96 \%-25 \%=71 \%)$, respectively (Table 2). These results are not consistent with earlier research by Viator et al. (2006) where sugarcane field residue extracts did not inhibit tomato seed germination.

Potential explanations for the differences between this experiment and that of Viator et al. (2006) include differences in sugarcane and tomato varieties, extract concentrations, and experimental design (extracts applied to seeds versus soil applied). Crop varieties can vary in their allelopathic activity and composition, whether the trait is intentionally or unintentionally incorporated into a varieties germplasm (Chen et al., 2008; Dilday et al., 
1994). For example, Eucalyptus camaldulensis Dehnh. leaf extracts also reduced tomato seed germination and radicle growth as the extract concentration increased, while a soil bioassay method did not detect the deleterious impact of the extracts (Fikreyesus et al., 2011). The results of this experiment correspond to earlier research by Webber et al. (2015a) where tomato seed germination was more sensitive to leaf residue extracts of kenaf (Hibiscus cannabinus L.) than to other plant parts, such as bark and core material (Webber et al., 2015a).

Table 2. Impact of sugarcane bagasse and field residue extract concentrations on tomato seed germination

\begin{tabular}{|c|c|c|c|c|c|}
\hline \multirow{2}{*}{$\begin{array}{l}\text { Extract Source \& } \\
\text { Concentration }\end{array}$} & \multicolumn{4}{|c|}{ Tomato Seed Germination } & \multirow{2}{*}{$\begin{array}{l}\text { Averaged across } \\
\text { Experiments }{ }^{\mathrm{Z}}\end{array}$} \\
\hline & Exp & riment 1 & $\mathrm{Ex}$ & iment 2 & \\
\hline & $\%$ & & $\%$ & & $\%$ \\
\hline \multicolumn{6}{|l|}{ Bagasse } \\
\hline $0 \mathrm{~g} / \mathrm{L}$ & 97 & $a^{Y}$ & 96 & $\mathrm{a}$ & 96.5 \\
\hline $16.7 \mathrm{~g} / \mathrm{L}$ & 95 & $\mathrm{a}$ & 94 & $a b$ & 94.5 \\
\hline $33.3 \mathrm{~g} / \mathrm{L}$ & 94 & $\mathrm{a}$ & 92 & $a b$ & 93.0 \\
\hline $66.7 \mathrm{~g} / \mathrm{L}$ & 89 & $a b$ & 83 & $\mathrm{~b}$ & 86.0 \\
\hline \multicolumn{6}{|l|}{ Field Residue } \\
\hline $0 \mathrm{~g} / \mathrm{L}$ & 97 & $\mathrm{a}$ & 96 & $\mathrm{a}$ & 96.5 \\
\hline $16.7 \mathrm{~g} / \mathrm{L}$ & 93 & $\mathrm{a}$ & 91 & $a b$ & 92.0 \\
\hline $33.3 \mathrm{~g} / \mathrm{L}$ & 89 & $a b$ & 87 & $a b$ & 88.0 \\
\hline $66.7 \mathrm{~g} / \mathrm{L}$ & 80 & $\mathrm{~b}$ & 25 & $\mathrm{c}$ & 52.5 \\
\hline
\end{tabular}

Note. ${ }^{\mathrm{Z}}$ The statistical analysis detected a significant treatment by experiment interaction. ${ }^{\mathrm{Y}}$ Means in a column followed by the same lower case letter are not significantly different at $\mathrm{P} \leq 0.05$, ANOVA.

\subsection{Chinese Kale}

Sugarcane bagasse extracts did not inhibit Chinese kale germination at any of the concentrations tested, unlike the field residue which severely decreased germination as the concentration increased from the lowest concentration $(0 \mathrm{~g} / \mathrm{L})$ to the highest concentration $(66.7 \mathrm{~g} / \mathrm{L})$ (Table 3$)$. Although the general trend between tomato and Chinese kale were similar for sugarcane field residue, the Chinese kale was highly sensitive to sugarcane field residue at 33.3 and $66.7 \mathrm{~g} / \mathrm{L}$ (Tables 2 and 3). Averaged across experiments, the sugarcane residue reduce Chinese kale germination by $82.5 \%(0 \mathrm{~g} / \mathrm{L}$ vs. $66.7 \mathrm{~g} / \mathrm{L})$ (Table 3$)$ compared to an average $44 \%$ decrease tomato germination $(0 \mathrm{~g} / \mathrm{L}$ vs. $66.7 \mathrm{~g} / \mathrm{L})$ (Table 2$)$.

Table 3. Impact of sugarcane bagasse and field residue extract concentrations on Chinese kale seed germination

\begin{tabular}{|c|c|c|c|}
\hline \multirow{2}{*}{$\begin{array}{l}\text { Extract Source \& } \\
\text { Concentration }\end{array}$} & \multicolumn{2}{|c|}{ Chinese Kale Seed Germination } & \multirow{2}{*}{$\begin{array}{l}\text { Averaged across } \\
\text { Experiments }{ }^{\mathrm{Z}}\end{array}$} \\
\hline & Experiment 1 & Experiment 2 & \\
\hline & $\%$ & $\%$ & $\%$ \\
\hline \multicolumn{4}{|l|}{ Bagasse } \\
\hline $0 \mathrm{~g} / \mathrm{L}$ & $a b^{Y}$ & 81 & 84.0 \\
\hline $16.7 \mathrm{~g} / \mathrm{L}$ & 79 & 75 & 77.0 \\
\hline $33.3 \mathrm{~g} / \mathrm{L}$ & 92 & 82 & 87.0 \\
\hline $66.7 \mathrm{~g} / \mathrm{L}$ & 85 & 76 & 80.5 \\
\hline \multicolumn{4}{|l|}{ Field Residue } \\
\hline $0 \mathrm{~g} / \mathrm{L}$ & $\mathrm{ab}$ & 81 & 84.0 \\
\hline $16.7 \mathrm{~g} / \mathrm{L}$ & $\mathrm{ab}$ & 43 & 66.5 \\
\hline $33.3 \mathrm{~g} / \mathrm{L}$ & 26 & 24 & 25.0 \\
\hline $66.7 \mathrm{~g} / \mathrm{L}$ & $\mathrm{d}$ & 0 & 1.5 \\
\hline
\end{tabular}

Note. ${ }^{\mathrm{Z}}$ The statistical analysis detected a significant treatment by experiment interaction. ${ }^{\mathrm{Y}}$ Means in a column followed by the same lower case letter are not significantly different at $\mathrm{P} \leq 0.05$, ANOVA. 


\subsection{Cucumber}

Sugarcane bagasse did not inhibit cucumber germination in either experiment (Table 4). These results were in contrast to the decrease in cucumber germination as sugarcane residue extract concentration increased (Table 4). Averaged across experiments, cucumber germination decreased from $89 \%$ to $0.5 \%$, at field residue concentrations from $0 \mathrm{~g} / \mathrm{L}$ and $66.7 \mathrm{~g} / \mathrm{L}$, respectively, an $88.5 \%$ reduction in germination (Table 4). In addition, cucumber germination in Experiment 1 was $0 \%$ for both the $33.3 \mathrm{~g} / \mathrm{L}$ and $66.7 \mathrm{~g} / \mathrm{L}$ field residue extract concentrations (Table 4). These results are consistent with Webber et al. (2015a) who reported a significant decrease in cucumber germination $(40 \%)$ when exposed to kenaf leaf extracts increased from $0 \mathrm{~g} / \mathrm{L}$ to $66.7 \mathrm{~g} / \mathrm{L}$.

Table 4. Impact of sugarcane bagasse and field residue extract concentrations on cucumber seed germination

\begin{tabular}{|c|c|c|c|c|c|}
\hline \multirow{2}{*}{$\begin{array}{l}\text { Extract Source \& } \\
\text { Concentration }\end{array}$} & \multicolumn{4}{|c|}{ Cucumber Seed Germination } & \multirow{2}{*}{$\begin{array}{l}\text { Averaged across } \\
\text { Experiments }{ }^{\mathrm{Z}}\end{array}$} \\
\hline & \multicolumn{2}{|c|}{ Experiment 1} & \multicolumn{2}{|c|}{ Experiment 2} & \\
\hline & $\%$ & & $\%$ & & $\%$ \\
\hline \multicolumn{6}{|l|}{$\underline{\text { Bagasse }}$} \\
\hline $0 \mathrm{~g} / \mathrm{L}$ & 95 & $\mathrm{a}^{\mathrm{Y}}$ & 83 & $\mathrm{a}$ & 89.0 \\
\hline $16.7 \mathrm{~g} / \mathrm{L}$ & 92 & a & 77 & $\mathrm{a}$ & 84.5 \\
\hline $33.3 \mathrm{~g} / \mathrm{L}$ & 97 & a & 77 & $\mathrm{a}$ & 87.0 \\
\hline $66.7 \mathrm{~g} / \mathrm{L}$ & 95 & a & 80 & $\mathrm{a}$ & 87.5 \\
\hline \multicolumn{6}{|l|}{ Filed Residue } \\
\hline $0 \mathrm{~g} / \mathrm{L}$ & 95 & $a^{Z}$ & 83 & $\mathrm{a}$ & 89.0 \\
\hline $16.7 \mathrm{~g} / \mathrm{L}$ & 66 & $\mathrm{~b}$ & 73 & $\mathrm{a}$ & 69.5 \\
\hline $33.3 \mathrm{~g} / \mathrm{L}$ & 0 & $\mathrm{c}$ & 35 & $\mathrm{~b}$ & 17.5 \\
\hline $66.7 \mathrm{~g} / \mathrm{L}$ & 0 & $\mathrm{c}$ & 1 & $\mathrm{c}$ & 0.5 \\
\hline
\end{tabular}

${ }^{\mathrm{Z}}$ The statistical analysis detected a significant treatment by experiment interaction. ${ }^{\mathrm{Y} M e a n s}$ in a column followed by the same lower case letter are not significantly different at $\mathrm{P} \leq 0.05$, ANOVA.

\section{Conclusions}

Sugarcane bagasse extracts did not inhibit Chinese kale and cucumber germination, and only adversely impacted tomato germination by $13 \%$ at the greatest concentration $(66.7 \mathrm{~g} / \mathrm{L})$ in 1 experiment. As the first documented bioassay implicating bagasse as having allelopathic activity, further research should investigate the subject, using higher concentrations and additional sugarcane and tomato varieties. Except for the one instance, it appears that sugarcane bagasse has potential as a natural mulch for vegetable production, although the mulch would only be a physical barrier to weed establishment, rather than a physical and chemical (allelpathic) barrier.

Seed germination decreased with increasing sugarcane field residue extract concentrations for all the vegetable species tested (tomato, Chinese kale, and cucumber). At the highest sugarcane residue extract concentration $(66.7 \mathrm{~g} / \mathrm{L})$, Chinese kale and cucumber seed germination inhibition followed a similar trend, decreasing an average over experiments by $82.5 \%$ and $88.5 \%$, respectively. Although the tomato seed germination decrease was not as great as that of the Chinese kale and cucumber, the highest sugarcane field residue concentration $(66.7 \mathrm{~g} / \mathrm{L})$ reduced germination by $44 \%(0 \mathrm{~g} / \mathrm{L}$ to $66.7 \mathrm{~g} / \mathrm{L})$. These results would indicate that sugarcane field residue would not be a suitable natural mulch or soil amendment for local vegetable production, especially where the vegetables were direct-seeded. If evaluated correctly, the sugarcane field residue may be an effective natural mulch for perennial ornamental or landscape applications providing both a physical and chemical barrier to germinating and emerging weed species. Research should be conducted with a selection of established perennial ornamental species and a range of weed seeds to determine the potential of sugarcane field residue on perennial plant growth and weed control. Future research should also investigate the allelopathic compounds present in the sugarcane field residue and determine if the same allelopathic chemicals are present and in the same concentration among sugarcane varieties commonly grown in Louisiana.

\section{Trade Names or Commercial Products}

Mention of trade names or commercial products in this publication is solely for the purpose of providing specific information and does not imply recommendation or endorsement by the U.S. Department of Agriculture. 


\section{EEO/Non-Discrimination Statement}

The U.S. Department of Agriculture (USDA) prohibits discrimination in all its programs and activities on the basis of race, color, national origin, age, disability, and where applicable, sex, marital status, familial status, parental status, religion, sexual orientation, genetic information, political beliefs, reprisal, or because all or part of an individual's income is derived from any public assistance program. (Not all prohibited bases apply to all programs.) Persons with disabilities who require alternative means for communication of program information (Braille, large print, audiotape, etc.) should contact USDA's TARGET Center at (202) 720-2600 (voice and TDD). To file a complaint of discrimination, write to USDA, Director, Office of Civil Rights, 1400 Independence Avenue, S.W., Washington, D.C. 20250-9410, or call (800) 795-3272 (voice) or (202) 720-6382 (TDD). USDA is an equal opportunity provider and employer.

\section{References}

Bowmick, P. C., \& Doll, J. D. (1982). Corn and soybean response to allelopathic effects of weed and crop residues. Agron. J., 74, 601-606. https://doi.org/10.2134/agronj1982.00021962007400040005x

Chen, X. H., Hu, F., \& Kong, C. H. (2008). Varietal improvement in rice allelopathy. Allelopathy J., 22(2), 379-384.

De Carvalho, G. J., De BastosAndrade, L. A., Gomide, M. B., \& De Figueiredo, P. A. M. (1996). Allelopathic potential of senescent leaves and green leaves and tips of sugarcane, in different concentrations of dry matter, upon the germination of lettuce seeds. Unimar Ciences, 5(2), 19-24.

Dilday, R., Lin, J., \& Yan, W. (1994). Identification of allelopathy in USDA-ARS rice germplasm collection. Australian Journal of Experimental Agriculture, 34, 907-910. https://doi.org/10.1071/EA9940907

Duke, S. O., \& Dayan, F. E. (2013). Clues to new herbicide mechanisms of action from natural sources. In J. Beck, J. Coats, S. O. Duke, \& M. Koivunen (Eds.), Pest Management with Natural Products (Vol. 1141, pp. 203-215). American Chemical Society, Washington, DC. https://doi.org/10.1021/bk-2013-1141.ch014

Facelli, J. M., \& Pickett, S. T. A. (1991) Plant litter: Its dynamics and effects on plant community structure. Bot. Rev., 57(1), 1-32. https://doi.org/10.1007/BF02858763

Fikreyesus, S., Kebebew, Z., Nebiyu, A., Zeleke, N., \& Bogale, S. (2011). Allelopathic effects of Eucalyptus camaldulensis Dehnh.on germination and growth of tomato. American-Eurasian J. Agric. \& Environ. Sci., 11(5), 600-608.

Gerwick, B. C., \& Sparks, T. C. (2014). Natural products for pest control: an analysis of their role, value and future. Pest Management Science, 70(8), 1169-1185. https://doi.org/10.1002/ps.3744

Lodhi, M. A. K., Bilal, R., \& Malik, K. A. (1987). Allelopathy in agroecosystems: Wheat phytotoxicity and possible roles in crop rotation. J. Chem. Ecol., 13(8), 1881-1891. https://doi.org/10.1007/BF01013237

Molisch, H. (1937). Der einfluss einer pflanze auf die andere. Allelopathic Fischer, Jena.

Nimbal, C. I., Yerkes, C. N., Weston, L. A., \& Weller, S. C. (1996). Herbicidal activity and site of action of the natural product sorgoleone. Pesticide Biochemistry and Physiology, 54(1), 73-83. https://doi.org/10.1006/ pest.1996.0011

Rice, E. L. (1984). Allelopathy (2nd ed., p. 422). Acedemic Press, New York.

Rodrigues, R. C. L. B., Felipe, M. G. A., Silva, J. B., Vitolo, M., \& Gómez, P. V. (2001). The influence of pH, temperature and hydrolyzate concentration on the removal of volatile and nonvolatile compounds from sugarcane bagasse hemicellulosic hydrolyzate treated with activated charcoal before or after vacuum evaporation. Brazilian Journal of Chemical Engineering, 18(3), 299-311. https://doi.org/10.1590/S010466322001000300009

Russo, V. M., Cartwright, C., \& Webber III, C. L. (1997a). Mulching effects on erosion of soil beds and on yield of autumn and spring planted vegetables. Biological Agriculture and Horticulture, 14, 85-93. https://doi.org/10.1080/01448765.1997.9754799

Russo, V. M., Webber III, C. L., \& Myers, D. L. (1997b). Kenaf extract affects germination and post-germination development of weed, grass and vegetable seeds. Ind. Crops Prod., 6, 59-69. https://doi.org/10.1016/ S0926-6690(96)00206-3

Sampietro, D. A., \& Vattuone, M. A. (2006a). Nature of the interference mechanism of sugarcane (Saccharum officinarum L.) straw. Plant Soil, 280, 157-169. https://doi.org/10.1007/s11104-005-2856-5 
Sampietro, D. A., \& Vattuone, M. A. (2006b). Sugarcane straw and its phytochemicals as growth regulators of weed and crop plants. Plant Growth Regul., 48, 21-27. https://doi.org/10.1007/s10725-005-5135-9

Sampietro, D. A., Sgariglia, M. A., Soberón, J. R., Quiroga, E. N., \& Vattuone, M. A. (2007). Role of sugarcane straw allelochemicals in the growth suppression of arrowleaf sida. Environmental and Experimental Botany, 60, 495-503. https://doi.org/10.1016/j.envexpbot.2007.02.002

Sampietro, D. A., Vattuone, M. A., \& Isla, M. I. (2005). Plant growth inhibitors isolated from sugarcane (Saccharum officinarum L.) straw. J. Plant Physiol., 163, 837-846. https://doi.org/10.1016/j.jplph. 2005.08.002

Singh, P., Suman, A., \& Shrivastava, K. (2003). Isolation and identification of allelochemicals from sugarcane leaves. Allelopathy J., 12(1), 71-80.

Takahashi, R., Hasegawa, K., Takano, A., \& Noguchi, T. (2010). Structures and binding sites of phenolic herbicides in the QB pocket of photosystem II. Biochemistry, 49(26), 5445-5454. https://doi.org/10.1021/ bi100639q

Tew, T. L., White, W. H., Legendre, B. L., Grisham, M. P., Dufrene, E. O., Garrison, D. D., ... Miller, J. D. (2005). Registration of 'HoCP 96-540' sugarcane. Crop Sci, 45(2), 785-786. https://doi.org/10.2135/ cropsci2005.0785a

Viator, R. P., Johnson, R. M., Grimm, C. C., \& Richard, E. P. (2006). Allelopathic, autotoxic, and hormetic effects of postharvest sugarcane residue. Agronomy Journal, 98(6), 1526-1531. https://doi.org/10.2134/ agronj2006.0030

Webber, C. L. III, White, P. M. Jr., Myers, D. L., Taylor, M. J., \& Shrefler, J. W. (2015a). Impact of kenaf (Hibiscus cannabinus L.) leaf, bark, and core extracts on germination of five plant species. Journal of Agricultural Science, 7(2), 93-98. https://doi.org/10.5539/jas.v7n2p93

Webber, C. L. III, White, P. M. Jr., Spaunhorst, D. J., \& Petrie, E. C. (2017). Comparative performance of sugarcane bagasse and black polyethylene as mulch for squash (Cucurbita pepo L.) production. Journal of Agricultural Science, 9(11), 1-9. https://doi.org/10.5539/jas.v9n11p1

Webber, C. L. III, White, P. M., Jr., Myers, D. L., Taylor, M. J., \& Shrefler, J. W. (2015b). Kenaf (Hibiscus cannabinus L.) impact on post-germination seedling growth. Journal of Agricultural Science, 7(12), 1-9. https://doi.org/10.5539/jas.v7n12p91

Wu, H., Haig, T., Pratley, J., Lemerle, D., \& An, M. (2002). Distribution and exudation of allelochemicals in wheat (Triticum aestivum). J. Chem. Ecol., 26(9), 2141-2154. https://doi.org/10.1023/A:1005520500110

\section{Copyrights}

Copyright for this article is retained by the author(s), with first publication rights granted to the journal.

This is an open-access article distributed under the terms and conditions of the Creative Commons Attribution license (http://creativecommons.org/licenses/by/4.0/). 